\title{
Benefits of the use of ICT in school activities by students with motor, speech, visual, and hearing impairment: a literature review
}

Helene Lidström and Helena Hemmingsson

\author{
Linköping University Post Print
}

Tweet

N.B.: When citing this work, cite the original article.

Original Publication:

Helene Lidström and Helena Hemmingsson, Benefits of the use of ICT in school activities by students with motor, speech, visual, and hearing impairment: a literature review, 2014, Scandinavian Journal of Occupational Therapy, (21), 4, 251-266.

http://dx.doi.org/10.3109/11038128.2014.880940

Copyright: Informa Healthcare http://informahealthcare.com/

Postprint available at: Linköping University Electronic Press

http://urn.kb.se/resolve?urn=urn:nbn:se:liu:diva-107351 


\title{
Benefits of using ICT in school activities by students with motor, speech, visual and hearing impairment: A literature review
}

\author{
HELENE LIDSTRÖM ${ }^{\mathrm{a}, \mathrm{b}, \mathrm{c}, 1}$ and HELENA HEMMINGSSON ${ }^{a}$ \\ a Department of Societal and Welfare Studies, Faculty of Health Sciences, Linköping \\ University, Sweden \\ ${ }^{b}$ Department of Women's and Children's Health, Faculty of Medicine, Uppsala University, \\ Sweden \\ c Department of Public Health and Caring Sciences, Faculty of Medicine, Uppsala \\ University, Sweden
}

${ }^{1}$ Corresponding Author. E-mail: helene.lidstrom@kbh.uu.se, Phone: +46 706110201 


\section{Abstract}

Introduction: Information and communication technology (ICT) has the potential to enhance participation in educational activities for students with physical disabilities. Even though incorporating ICTs into teaching and learning in education has become an important issue, it is unclear what evidence research has provided. Aim: To investigate type of ICT items and how ICT is being used by students with physical disabilities, and describe benefits of ICT use in school activities. Method: A systematic literature search, covering the period 2000-May 2012, was performed in the databases AMED, CINAHL, Eric, OTseeker, Psych Info, PubMed, and Scopus. Data analysis entailed extracting, editing, grouping, and abstracting findings. Results: A total of 32 articles were included, 16 of which were intervention studies. More than half of the studies concerned students with motor impairments. Type of ICT used differed among impairment groups, and ICT seemed to be especially beneficial for writing, spelling and communication. Conclusion: Even though the review found heterogeneity across the studies students seemed to benefit from ICT use regardless of the type. For future research it is important to highlight intervention studies especially for students with visual, hearing and communication impairments. 


\section{Introduction}

The rationale for using information and communication technology (ICT), technologies for the manipulation and communication of information through voice and sound, or images such as computers, computer-based assistive technology, special software, communication aids, in schools by students with physical disabilities is to prepare all students for participation in the information society $(1,2)$. Incorporating ICTs, particularly computers and the Internet, into teaching and learning in education to increase the students "digital skills" has therefore become an important issue in both economically developed and rapidly developing countries (3-7). Consequently, from an equality perspective, all students should have equal opportunity and appropriate support to acquire competence with the technology, irrespective of whether they have a physical disability or not $(8,9)$. However, for students with disabilities, the literature appears to support the use of ICT as an assistive technology device (ATD), specifically designed to assist and enable an individual's participation, to a varying degree, in all occupational performance areas, but particularly in education, communication and play (1012).

Despite ICTs have been available in schools in many western countries in some decades, much of the research on using ICT in education has focused on benefits by children without disabilities $(1,3,4,13)$. Empirical research is spare in regard to how ICT enhances the participation of children with physical disabilities in school activities $(14,15)$. However, the literature has emphasised that ICT, as a computer-based ATD has the potential to enable children with physical disabilities to participate more fully in everyday activities, e.g. access to the class curriculum $(14,16-18)$. The World Health Organization (WHO) for example stresses that ATDs are one strategy that can be used by children with disabilities to improve functioning and minimize the impact of environmental barriers to their participation in everyday life, such 
as school activities (19). Therefore, research into the benefits of ICT use for participation in school activities for these students is needed $(20,21)$.

Regarding children and youths with physical disabilities i.e. children with motor impairment (e.g. cerebral palsy, acquired brain injury), speech (communication), visual (blind, low vision) and hearing impairment (deaf, hearing loss), several studies have shown that their participation in school activities is restricted when compared with children without disabilities $(18,22-24)$. In International Classification of Functioning, Disability and Health- children and youth version (ICF-CY) participation is consistent with "an individual's involvement in a life situation" (19). Participation is also an essential aspect of children's health and well-being. Through participation in school children acquire academic knowledge, but also learn about the expectations of society, learn to communicate and get along with others and develop the skills and competencies they need to become successful in their communities, thus gain increased opportunities to work in adult life $(19,25)$. Although the literature suggests that ICT has the potential to enhance participation for children with disabilities in everyday activities $(14,26-$ 30), it is unclear what evidence research has provided whether ICT enhances participation in educational activities (31). In addition, scholars (2) argue that studies on the quality of technology use are lacking in this research area, i.e. how technology is used, why and the benefit of use. A literature review will find out if empirical studies into the benefits of ICT use in school activities for students with physical disabilities are still needed. Therefore, the aim of the review is to investigate, type of ICT items and how ICT is being used by students with physical disabilities, and describe benefits of ICT use in school activities.

\section{Method}

\section{Inclusion and exclusion criteria}

This literature review followed a systematic and structured methodological approach (32-34). The authors started by constructing a list of inclusion criteria that were intended to guide the 
search for articles. Inclusion criteria for the first database search were: a) only primary research, b) both qualitative and quantitative studies, c) articles published in English-language peer-reviewed journals, d) articles published in this century (from January 2000 to May 2012), on the basis of the rapid technical development, e) a study population of students with physical disabilities between 6- 19 years of age, e) intervention studies with some type of ICT and f) benefits measured needed to address the use of ICT in school activities.

Initially, the intention was to include only intervention articles where the focus was on the outcome of ICT use in school activities. When the articles were read in full text, it appeared that many of the studies consisted of cross-sectional and descriptive designs, and the test environments were also often rehabilitation centres and clinics. Therefore, the inclusion criteria were revised to also include: descriptive studies. The use of ICT in "school activities" were accepted to be performed in environments other than schools, for example the rehabilitation clinic if the ICT were intended to be used in school.

Thus, studies that focused solely on outcomes relating to the ICT product design were excluded.

\section{Search strategy}

To locate and identify relevant articles a range of electronic databases (AMED, CINAHL, Eric, OTseeker, Psych Info, PubMed, Scopus) and reference and related citation lists in included articles were used (32). Beyond this, the journals Assistive Technology, Technology and Disability, and Disability and Rehabilitation: Assistive and Technology (available from 2006 volume: 1) were manually searched for the period 2000 to May 2012.

Following Schlosser, Koul and Costello (35) the template PICO (patient, intervention, comparison and outcome) was used for asking of a well-constructed question and finding words for searching. The searches undertaken used combinations of the Patient: physical 
Running head: BENIFITS OF USING ICT IN SCHOOL

disabilities OR disabled children OR hearing impairment OR visual impairment OR speech impairment AND some of following search words for the Intervention: ICT OR information communication technology OR computer OR computer-based assistive technology AND assistive technology OR self-help devices and the Outcome: education OR school work OR educational activities OR participation OR engagement. Comparison, i.e. the C in PICO was not topically in present review.

\section{Search outcome}

The database search resulted in 603 relevant titles which were screened by the first author, resulting in 325 identified abstracts. A manual search in the above-mentioned assistive technology journals resulted in another 3 abstracts. Duplicates and abstracts that clearly did not fulfil the inclusion criteria were excluded $(n=212)$. Therefore, 116 abstracts were retrieved in full-article form to judge all the inclusion criteria. Of these, 82 articles were rejected, e.g. because of the study population was students without physical disabilities, or the participants were adults. The first author read each of the 34 articles, and scanned the reference lists of these articles. Additional articles were found when the reference lists in the included articles were scanned $(n=7)$. The number of articles included into this step comprised 41 full-text articles. Figure I describes the selection process. 


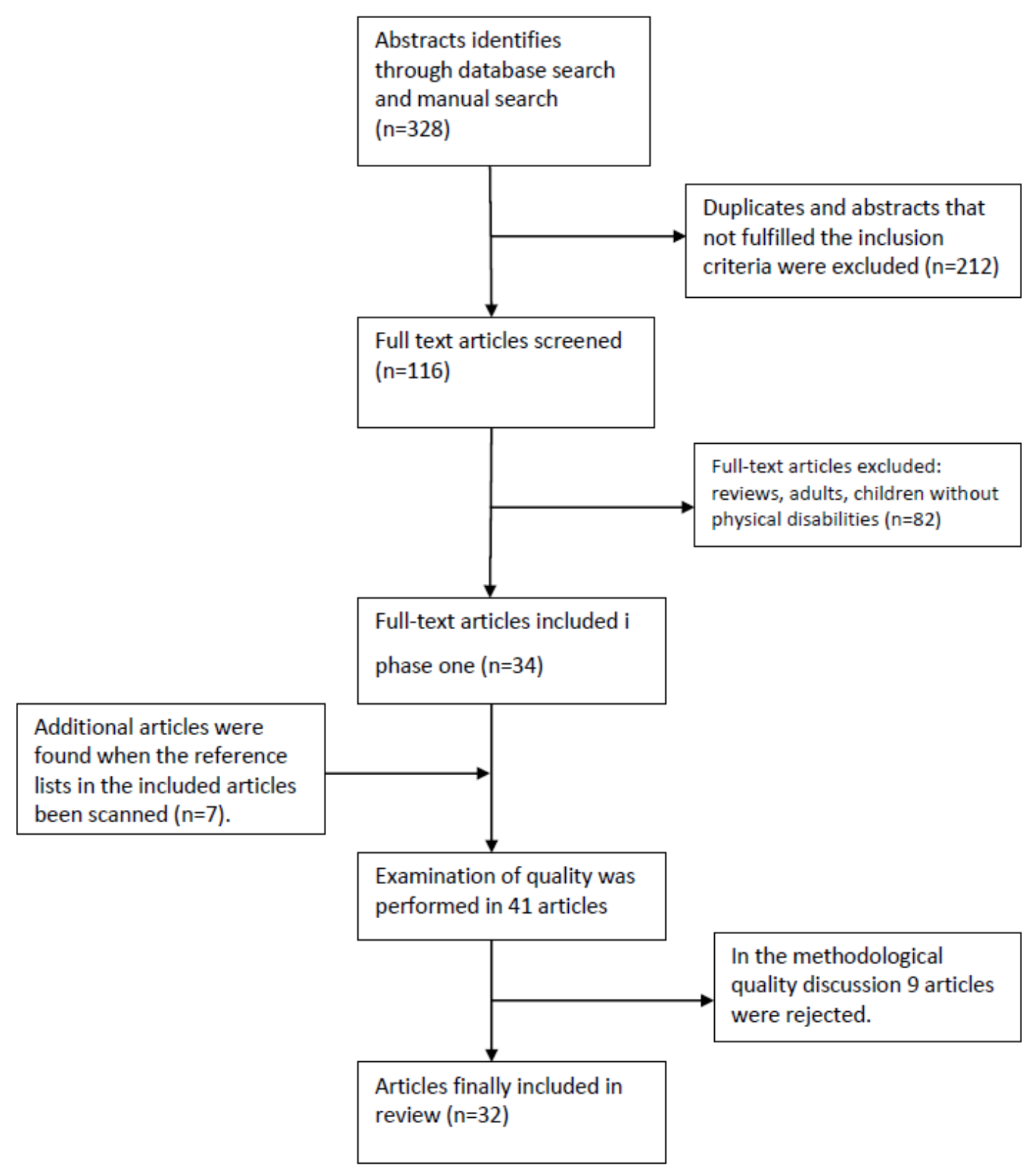

Figure I Flow-chart showing the process of identifying and selecting the included articles. 


\section{Data extraction and analysis}

The Research Pyramid (36) has given the arguments for inclusion of both qualitative and quantitative research in this literature review. The critical review forms for quantitative and qualitative studies developed by the Occupational Therapy Evidence-Based Practice Group at McMaster University, Canada (37-39) were used to evaluate internal validity. These forms allow the reviewer to summarize information and evaluate the quality of the studies' purpose, background literature, design of the study, sample size, outcome measures, interventions and results. When the methodological quality was discussed by the authors, nine articles were rejected from the 41 full-text articles.

To compare and contrast the results of each study, data were extracted and organized in a matrix (32). In the first phase the matrix was used to classify each article into categories, according to the type of research used: author/s/, year, country of origin, design, sample and measurement, purpose of the study, purpose of ICT use, as well as reported outcome of ICT use. In the next phase in the analysis process the completed matrix was used to group the studies reviewed in terms of students with mild and severe motor impairment, speech, visual and hearing impairment. In the third phase, type of ICT was identified and classified in relation to the type of impairment group. Four ICT categories emerged: 1) text-generating hard- and software (e.g. computer, word processing, word prediction software), 2) speech-generating hard- and software (e.g. communication aids, text-to-speech device, speech synthesizer), 3) access solutions (e.g. computer input interface, screen-keyboard), and 4) special software (e.g. software for education in maths, spelling, multimedia software). In the last phase the benefits of ICT use in each ICT category were analysed with the help of the matrix and the analysis in phase three, that is, ICT type in relation to type of impairment group. 


\section{Results}

A total of 32 studies met the inclusion criteria for this review, presented in Tables II-VI. The countries of origin for the studies reveal that about one third of the 32 studies were conducted in the U.S.A. $(n=12)$, the remainder were conducted in Canada $(n=5)$, Australia $(n=4)$, Sweden $(n=3)$, Italy and Brazil $(n=2)$, and one in Finland, Israel, the Netherlands, and Spain, respectively. No studies were found from Asian and African countries.

\section{Methodological aspects}

In the present review, most of the studies $(n=26)$ have a quantitative design: two with cohort designs $(40,41)$, single-subject design $(n=4)(42-45)$, before-after design $(n=10)(46-55)$, casestudy design (descriptive) $(n=5)(56-60)$, and six studies with a cross-sectional design $(n=6)$ (61-66). Five studies have a qualitative design (67-71).

Table I presents the sample sizes in the four studied groups of students, that is, students with motor, speech, visual and hearing impairment. Altogether, two third of the studies reported a range of participants numbers from one to 15 . In the group of students with speech impairment, all five studies had fewer than sixteen participants. All studies with students with hearing loss had between 6 and 30 participants. 
Table I. Student groups in relation to sample sizes of participants (students, or their parents, teachers, therapists) in the studies.

\begin{tabular}{|c|c|c|c|c|}
\hline \multirow[b]{2}{*}{ Student group } & \multicolumn{4}{|c|}{ Sample sizes } \\
\hline & $1-5$ & $6-15$ & $16-30$ & $\begin{array}{c}\text { Over } \\
30\end{array}$ \\
\hline $\begin{array}{l}\text { Students with motor } \\
\text { impairments (n=17) }\end{array}$ & 7 & 3 & 5 & 2 \\
\hline $\begin{array}{l}\text { Students with speech } \\
\text { impairments }(n=5)\end{array}$ & 2 & 3 & & \\
\hline $\begin{array}{l}\text { Students with visual } \\
\text { impairments ( } n=5 \text { ) }\end{array}$ & 1 & 2 & & 2 \\
\hline $\begin{array}{l}\text { Students with hearing loss } \\
(n=5)\end{array}$ & & 2 & 3 & \\
\hline
\end{tabular}

In the review, more than half of the studies (17/32) concerned students with motor impairments use of ICT seven studies of these involved students with handwriting difficulties (42-44, 46-48, 66) (Table II) and 10 with students profound motor impairment $(45,49,50,57,61-64,67,71)$ (Table III). The remaining 15 studies were divided equally into students with speech impairment $(51-53,68,69)$ (Table IV), students with visual impairment $(56,58,59,65,70)$ (Table V) and finally, students with hearing impairment $(40,41,54,55,60)$ (Table VI).

Half of the studies (16/32) (40-55) were intervention studies, where academic skills were addressed in nine studies (40-44, 46, 47, 51, 53, 55), and skill improvement in the use of the computer was targeted in six of the included studies $(45,48-50,52,54)$. The focuses of five studies were product development (56-60). In these studies new types of devices and software, e.g. talking tactile tablet, multi-camera tongue switch, software in a virtual reality immersive environment, were tested in different school activities, e.g. learning math or writing. The remaining eleven descriptive studies delineated the use and non-use of ICT (e.g. access, satisfaction, as well as which activities) in school activities (61-70). 


\section{Type of ICT items and how ICT is used for students with physical disabilities}

\section{Students with mild to severe motor impairments}

Six (42-44, 46-48) out of seven studies in students with mild motor impairment with handwriting difficulties (Table II) described and evaluated the use of a combination of textgenerating hard- and software; computers and software, such as word processing, word prediction and or word-cueing programs. Use of computers and word-processing programs with and without word-prediction software has been studied by examining legibility $(42,44,46,47)$, speed in writing $(42-44,46-48)$, amount of written text $(42-44,47)$ but also the number of correctly spelled words $(42,44,46-48)$ before and after the treatment period.

\begin{tabular}{|c|c|c|c|c|}
\hline Source/Country & \begin{tabular}{|l} 
Handley-More et al. (2003)/ U.S.A. \\
(42)
\end{tabular} & Hetaroni et al. (2004)/ larzel (43) & Klein et al. (2008) U.S.A. (44) & Miranda and Turoldo (2006)/Canada (46) \\
\hline $\begin{array}{l}\text { Purpose of the } \\
\text { study }\end{array}$ & $\begin{array}{l}\text { To investigate whether word } \\
\text { processing and word prediction were } \\
\text { effective in improving the written } \\
\text { communication skills of children with } \\
\text { learning disabilities and handwriting } \\
\text { problems. }\end{array}$ & $\begin{array}{l}\text { To investigate the use of a word } \\
\text { processor for enhancing the academic } \\
\text { outcomes of students with writing } \\
\text { disabilities in a lower-secondary school. }\end{array}$ & $\begin{array}{l}\text { To explore the potential of children with } \\
\text { DCD to learn computer use, keyboarding } \\
\text { and basic word-processing skills, and to } \\
\text { compare the speed of their keyboarding } \\
\text { with printing/handwriting. }\end{array}$ & $\begin{array}{l}\text { To examine the impact of a word- } \\
\text { prediction software program, on the } \\
\text { written output of students with physical } \\
\text { disabilities that affected their ability to } \\
\text { write by hand. }\end{array}$ \\
\hline Sample/Age & $N=3$, in grades 4 and 5 . & $\mathrm{N}=3,12$ to 13 years old. & $N=6$, age 7 to 10 & $N=24$, age 8 to 19 \\
\hline $\begin{array}{l}\text { Type and } \\
\text { purpose of ICT } \\
\text { use }\end{array}$ & \begin{tabular}{|l|} 
Computer, word-processing and \\
word-prediction software. To produce \\
more legible written work, faster and \\
with decreased spelling errors.
\end{tabular} & $\begin{array}{l}\text { Computer, word-processing software. To } \\
\text { increase the written outcome and for } \\
\text { enhancing individual productivity. }\end{array}$ & $\begin{array}{l}\text { Computer, computer-skills program. To } \\
\text { produce more legble written work, faster } \\
\text { and with decreased spelling errorz. }\end{array}$ & $\begin{array}{l}\text { Computer, word-processing, word- } \\
\text { prediction software. To produce more } \\
\text { leg ble written work, faster, increase total } \\
\text { amount and with decreased spelling } \\
\text { errorz. }\end{array}$ \\
\hline $\begin{array}{l}\text { How ICT was } \\
\text { measured }\end{array}$ & \begin{tabular}{|l|} 
A aingle-subject alternating \\
treatments design was replicated. \\
Percentages of legible words and \\
correctly spelled words, total amount \\
written, and rate of writing were \\
assessed. Alternating among \\
handwriting, word processing and \\
word processing with word prediction
\end{tabular} & $\begin{array}{l}\text { Intervention in an ABAB design with a } \\
\text { training phase between phases A1 and } \\
\text { B1. Pre-and post-test assessed per cent } \\
\text { of spelling and reading errors, total } \\
\text { numbers of words were assessed and } \\
\text { structure and organization of the text. }\end{array}$ & $\begin{array}{l}\text { Intervention in an ABAB design, with five } \\
\text { replications. The computer skills program } \\
\text { consisted of } 10 \text { one-hour sessions. Pre-and } \\
\text { post-test were done in a printing/ } \\
\text { handwriting task, with a computer skills } \\
\text { checklist and in an observation sheet. }\end{array}$ & $\begin{array}{l}\text { Intervention with word-processing and } \\
\text { word-prediction software. A student } \\
\text { aurvey and three writing samples where } \\
\text { each student write for } 10 \text { minutes using } \\
\text { handwriting and computer with word- } \\
\text { processing software only, and a computer } \\
\text { with both word-processing and word- } \\
\text { prediction software. }\end{array}$ \\
\hline \begin{tabular}{|l|} 
Reported benefit \\
of ICT use
\end{tabular} & $\begin{array}{l}\text { Results were variable. Two children } \\
\text { had significantly improvements in } \\
\text { leg bility (either word processing } \\
\text { alone or with word prediction) and in } \\
\text { spelling (word prediction). Though } \\
\text { rate of writing was best for two } \\
\text { children when using handwriting; } \\
\text { relative to total amount produced; } \\
\text { one method was not clearly } \\
\text { preferable to another. }\end{array}$ & $\begin{array}{l}\text { In paper-and-pencil phases, students } \\
\text { produced outcomes that had more } \\
\text { spelling mistakes, more reading errora, } \\
\text { and lower overall quality of organization } \\
\text { and structure in comparison with use of } \\
\text { computer and a word processor. The } \\
\text { results did not indicate any noticeable } \\
\text { difference in the number of words per } \\
\text { sext. }\end{array}$ & $\begin{array}{l}\text { All children showed improved word } \\
\text { processing skills. Touch keyboarding speed } \\
\text { increased for the five children but only } \\
\text { one child acquired a speed comparable to } \\
\text { printing/handwriting. Four children } \\
\text { demonstrated increased text production } \\
\text { when generating a story, but none } \\
\text { achieved speeds comparable to printing/ } \\
\text { handwriting. Therapists observed } \\
\text { improved legibility and increased } \\
\text { motivation. }\end{array}$ & $\begin{array}{l}\text { Both word processing and word prediction } \\
\text { positively affected legibility, but only word } \\
\text { prediction positively affected spelling } \\
\text { accuracy in comparison to handwriting. } \\
\text { Co-Writer also had a positive impact on } \\
\text { writing quality in comparison with both } \\
\text { handwriting and word processing, as } \\
\text { measured by the percentage and mean } \\
\text { length of consecutive correct word } \\
\text { sequences. }\end{array}$ \\
\hline
\end{tabular}

All studies in students with severe motor impairment included uses of computer and an access solution (Table III). These access solutions ranged from newly developed products, e.g. voicedetecting sensor (49), micro switch and keyboard emulator (45) and contact tongue protrusion 
(57), as well as commercial products, such as switches and screen keyboards (50). The computer and the different access solutions were studied to facilitate students writing $(45,49)$, to interact with their surroundings (57), and to contribute to attaining students' Individual Education Programme (IEP) goals (50).

\begin{tabular}{|c|c|c|c|c|c|}
\hline urce/Country & Brodin (2010)/ Sweden (61) & $\begin{array}{l}\text { Hemmingsson et al. (2009) } \\
\text { Sweden (71) }\end{array}$ & Lancioni et al. (2009)/ Italy (49) & Lancioni et al. (2011)/ Italy (45) & $\begin{array}{l}\text { Leung \& Chau (2010)/ Canada } \\
\text { (57) }\end{array}$ \\
\hline $\begin{array}{l}\text { urpose of the } \\
\text { udy }\end{array}$ & $\begin{array}{l}\text { To ascertain whether ICT is used in } \\
\text { achools to support inclusion and } \\
\text { equal opportunities for children with } \\
\text { motor disabilities. How do parents } \\
\text { evaluate the use of computers at } \\
\text { school? How are the communicative } \\
\text { aspects of ICT used in the classroom? }\end{array}$ & \begin{tabular}{|l|} 
The use and non-use of assistive \\
technology devices in school by \\
students with physical disabilities \\
was investigated, and the \\
students' experiences in using \\
these devices are described.
\end{tabular} & \begin{tabular}{|l|} 
To compared the effects of the \\
voice-detecting sensor with those \\
of a familiar pressure sensor.
\end{tabular} & $\begin{array}{l}\text { To assess the effectiveness of } \\
\text { micro switches for simple } \\
\text { responses and a keyboard } \\
\text { emulator to facilitate the } \\
\text { writing performance of three } \\
\text { participants with extensive } \\
\text { motor disabilities. }\end{array}$ & $\begin{array}{l}\text { To investigate a video-based } \\
\text { access technology that facilitated } \\
\text { a non-contact tongue protrusion } \\
\text { access modality for a } 7 \text {-year-old } \\
\text { boy with severe spastic } \\
\text { quadriplegic cerebral palsy. }\end{array}$ \\
\hline mple/Age & $\mathrm{N}=16$ families, and a 15 -year-old boy. & $\begin{array}{l}\mathrm{N}=20,8 \text { to } 19 \text { years, and their } \\
\text { occupational therapists. }\end{array}$ & $\mathrm{N}=2,12.7$ and 10.4 years old. & $N=3,13,45$ and 46 years old & $N=1,7$-years. \\
\hline $\begin{array}{l}\text { Type and } \\
\text { purpose of ICT } \\
\text { use }\end{array}$ & $\begin{array}{l}\text { Computer, Internet, computer-based } \\
\text { ATD, educational programs. For } \\
\text { communication and inclusion to } \\
\text { contribute equal opportunitie in and } \\
\text { outside school. }\end{array}$ & $\begin{array}{l}\text { Computer, computer-based ATD, } \\
\text { communication aid. To } \\
\text { participate in school activities. }\end{array}$ & $\begin{array}{l}\text { Computer, a voice-detecting } \\
\text { sensor, a scanning keyboard } \\
\text { emulator. To write and for } \\
\text { communication. }\end{array}$ & 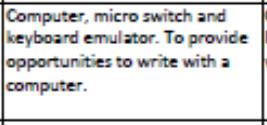 & $\begin{array}{l}\text { Computer, tongue-switch. } \\
\text { Interact with their surrounding } \\
\text { world. }\end{array}$ \\
\hline $\begin{array}{l}\text { ICT was } \\
\text { ssured }\end{array}$ & $\begin{array}{l}\text { Descriptive from the parents' } \\
\text { perspective for the most part. A } \\
\text { parental questionnaire and an } \\
\text { interview with one pupil. }\end{array}$ & $\begin{array}{l}\text { Descriptive after intervention } \\
\text { with an ATD from students' } \\
\text { perspective. Semi-structured } \\
\text { interview. }\end{array}$ & \begin{tabular}{|l|} 
Intervention with an access \\
solution. The performance with \\
two type of access solutions, and \\
a social validation check of their \\
performance.
\end{tabular} & \begin{tabular}{|l|} 
Intervention in an ABAB design. \\
The time required for writing \\
the words provided, the \\
participants' answers to the \\
preference checks before and \\
after the intervention.
\end{tabular} & $\begin{array}{l}\text { A descriptive case study in } \\
\text { product development. Testing the } \\
\text { access solutions in a computer } \\
\text { game with matching. }\end{array}$ \\
\hline $\begin{array}{l}\text { orted } \\
\text { efit of ICT }\end{array}$ & $\begin{array}{l}\text { Seven of fourteen parents describe } \\
\text { that the computer improved } \\
\text { communication (Internet, chat } \\
\text { friends on the Web) and interaction } \\
\text { with others. Fourteen of the parents } \\
\text { reported difficulties with computer } \\
\text { use at school and stressed that the } \\
\text { competence was low among the } \\
\text { teachers. }\end{array}$ & $\begin{array}{l}\text { The main characteristics of ATDs } \\
\text { that students with disabilities } \\
\text { appreciated and wanted to use in } \\
\text { school were the ATD's integration } \\
\text { into teaching and learning and } \\
\text { the students' experience of the } \\
\text { ATD as enabling functioning in } \\
\text { everyday school activities without } \\
\text { threatening or complicating their } \\
\text { social participation with peers. }\end{array}$ & $\begin{array}{l}\text { The difference before and after in } \\
\text { the boyz' overall mean writing } \\
\text { time per letter across sensors } \\
\text { was, about } 1.5 \mathrm{~s} \text {. This difference } \\
\text { favoured the pressure sensor for } \\
\text { one of the boys and the voice-- } \\
\text { detecting sengor for the other } \\
\text { boy. Both boys showed } \\
\text { preference for the voice-detecting } \\
\text { sensor. }\end{array}$ & \begin{tabular}{|l|} 
The participated child had a \\
faster writing performance \\
during the B phasea. The micro \\
switch was considered relatively \\
easy and convenient to manage \\
and did not seem to cause any \\
specific signs of tiredness.
\end{tabular} & $\begin{array}{l}\text { Non-contact tongue protrusion } \\
\text { modality via multiple camera } \\
\text { video-based techniques can be a } \\
\text { viable paediatric access pathway } \\
\text { within a controlled environment } \\
\text { for children with severe motor } \\
\text { impairment. }\end{array}$ \\
\hline
\end{tabular}

\section{Students with speech impairment}

Table IV shows speech-generating hard- and special software studied in five studies, used in students with speech impairment. The three intervention studies focused on increasing the students' communication skills $(51,53)$ and spelling performance (52). Because students with speech impairment often had severe motor impairment, an access solution was needed as an input tool for the computer-based communication aids $(53,68)$, which often consisted of a screen keyboard which in turn controls a variety of software applications. These access solutions were not investigated in these included studies. 
Table IV. Studies included show use of ICT in students with speech impairment

\begin{tabular}{|c|c|c|c|}
\hline $\begin{array}{l}\text { Source/ } \\
\text { Country }\end{array}$ & Carpe, et al. (2010)/ Canada (68) & Kent-Walsh et al. (2003)/ U.S.A. (69) & Myers (2007)/U.S.A (51) \\
\hline $\begin{array}{l}\text { Purpose of the } \\
\text { study }\end{array}$ & $\begin{array}{l}\text { To explore the perceptions of } \\
\text { children with physical disabilities } \\
\text { regarding their writing and } \\
\text { communication aids. }\end{array}$ & $\begin{array}{l}\text { To investigate the experiences of } \\
\text { general education teachers who had } \\
\text { included students with AAC in their } \\
\text { classes. }\end{array}$ & $\begin{array}{l}\text { To enhance the language and literacy } \\
\text { skills of the participants to increase } \\
\text { their participation in school activities. }\end{array}$ \\
\hline Sample/Age & $\begin{array}{l}\mathrm{N}=10 \text {, age } 8-18 \text { years, } 1 \text { parent and } \\
2 \text { OTs. }\end{array}$ & $\begin{array}{l}\mathrm{N}=11 \text { education teachers of } \\
\text { students with } \mathrm{AAC} \text { aged } 6-17 \text { years. }\end{array}$ & $\mathrm{N}=4$, age $5-9$ \\
\hline $\begin{array}{l}\text { Type and } \\
\text { purpose of ICT } \\
\text { use }\end{array}$ & $\begin{array}{l}\text { Text- and Speech-generating hard- } \\
\text { and software, access solutions. } \\
\text { Portable writing and communication } \\
\text { aids enabling written productivity } \\
\text { and literacy, and enabling } \\
\text { community and school participation. }\end{array}$ & $\begin{array}{l}\text { Speech-generating hard- and } \\
\text { software (communication aids). To } \\
\text { increase students' speech and the } \\
\text { interaction with their typically } \\
\text { classmates in classroom activities. To } \\
\text { increase educational gains. }\end{array}$ & $\begin{array}{l}\text { Speech-generating hardware and } \\
\text { communication aids, computer/ } \\
\text { communication software. To progress } \\
\text { communication competence and } \\
\text { increase participation and } \\
\text { independence. }\end{array}$ \\
\hline $\begin{array}{l}\text { How ICT was } \\
\text { measured }\end{array}$ & $\begin{array}{l}\text { Children: in-depth interview. Parent } \\
\text { and OTs: focus group. }\end{array}$ & $\begin{array}{l}\text { Semi-structured interview with } \\
\text { teachers. }\end{array}$ & $\begin{array}{l}\text { An intervention programme with AAC } \\
\text { in } 4 \text { weeks. Follow-up in school. }\end{array}$ \\
\hline $\begin{array}{l}\text { Reported } \\
\text { benefit of ICT } \\
\text { use }\end{array}$ & $\begin{array}{l}\text { Findings indicate that portable } \\
\text { writing and communication aids are } \\
\text { more than a means to enable } \\
\text { written productivity and literacy. } \\
\text { They also may help enable } \\
\text { community and school participation, } \\
\text { building of social relationships, and } \\
\text { positive feelings of self. }\end{array}$ & $\begin{array}{l}\text { The target students' speech and skill } \\
\text { in operating their AAC systems } \\
\text { improved when interacting with } \\
\text { their typical classmates in classroom } \\
\text { activities. Despite this, the students } \\
\text { have been observed being excluded } \\
\text { by their peers outside of the } \\
\text { classroom. Whether use of AAC } \\
\text { made educational gains or not was } \\
\text { not assessed. }\end{array}$ & $\begin{array}{l}\text { All students made progress in } \\
\text { communication competence during } \\
\text { the intervention period. Increased } \\
\text { participation and independence were } \\
\text { demonstrated for two participants in } \\
\text { the follow-up in school. Computers } \\
\text { and communication software were } \\
\text { more familiar to school than complex } \\
\text { dedicated devices. }\end{array}$ \\
\hline
\end{tabular}

\section{Students with visual impairments}

In Table $\mathrm{V}$ shows five studies in students with visual impairment and their use of ICT. Four of these had studied the students' use of speech-generating hardware together with special software applications $(56,58,65,70)$. In two studies new ICT items were tested with the purpose of making graphical elements in maths accessible $(56,58)$. In addition, an access solution system (single-switch text-entry system) was investigated to enable a student with visual impairment and severe motor impairment to use the computer for writing (59). The special maths software (56), the Talking Tactile Tablet (58) and an advanced text-entry solution 
(59) were newly available devices and the students' performances were measured with and without the new products.

Table V. Studies included show in use of ICT in students with visual impaiment

\begin{tabular}{|c|c|c|c|c|c|}
\hline \begin{tabular}{|l|}
$\begin{array}{l}\text { Source/Countr } \\
\mathrm{y}\end{array}$ \\
\end{tabular} & 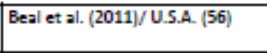 & \begin{tabular}{|l|}
$\begin{array}{l}\text { De Freitas Alves et al. (2009) } \\
\text { Brazil (65) }\end{array}$ \\
\end{tabular} & Kelly (2009)/ U S.A. (70) & | Landau et al., (2003) /U.S.A (58) & \begin{tabular}{|l|}
$\begin{array}{l}\text { Leung et al. (2010)/ Canada } \\
\text { (59) }\end{array}$ \\
\end{tabular} \\
\hline Sample/Age & $N=14$, in grades 5-12. & $\begin{array}{l}\mathrm{N}=134 \text { education teachers, } 58 \text { of } \\
\text { these teach students with visual } \\
\text { impairment. }\end{array}$ & $\mathrm{N}=297$, aged $6-16$ years. & $\mathrm{N}=8, \ldots$ & $N=1,11$-year. \\
\hline $\begin{array}{l}\text { How ICT was } \\
\text { measured }\end{array}$ & $\begin{array}{l}\text { Product development. Students' } \\
\text { performance was ascessed by } \\
\text { percentage of correct answers } \\
\text { and the number of incorrect } \\
\text { answer attempts on each } \\
\text { problem. }\end{array}$ & $\begin{array}{l}\text { Descriptive from teachers } \\
\text { perspective. Survey }\end{array}$ & $\begin{array}{l}\text { Descriptive from parents', teachers', } \\
\text { collaboratorg' perspectives. } \\
\text { Structured interview in three waves of } \\
4 \text { years }\end{array}$ & $\begin{array}{l}\text { Product development with } \\
\text { experimental design. Two test } \\
\text { forms were administered both in } \\
\text { the standard accommodation } \\
\text { and on the TIT. The third form } \\
\text { was administered only on the } \\
\text { III. }\end{array}$ & $\begin{array}{l}\text { A descriptive case study with } \\
\text { product development. } \\
\text { Testing the character stroke } \\
\text { disambiguation system in a } \\
\text { word processor }\end{array}$ \\
\hline
\end{tabular}

\section{Students with hearing impairment}

Students with hearing impairment using computers with special multimedia software applications were found in five articles, as can be seen in Table VI. Purposes of the use of special software in teaching were to facilitate learning of mathematics (60), to increase vocabulary for communication $(54,55)$, and reading $(40)$. 
Table VI Studies included show use if of ICT in students with hearing impaiment

\begin{tabular}{|c|c|c|c|c|c|}
\hline \begin{tabular}{|l|} 
Source/ \\
Country
\end{tabular} & \begin{tabular}{|l}
$\begin{array}{l}\text { Adamo-Villani et al. (2010)/ U.S.A. } \\
(60)\end{array}$ \\
\end{tabular} & $\begin{array}{l}\begin{array}{l}\text { Massaro et al. }(2004) / \text { U.S.A. } \\
\text { (54) }\end{array} \\
\end{array}$ & Perin da Silva (2012)/Brazil (41) & Reitsma (2009)/ Netherlands (55) & Trezek et al., (2003) U.S.A. (40) \\
\hline $\begin{array}{l}\text { Purpose of } \\
\text { the study }\end{array}$ & $\begin{array}{l}\text { To describe the development steps } \\
\text { of two novel approaches to teaching } \\
\text { maths and science to deaf children } \\
\text { using } 30 \text { animated interactive } \\
\text { software }\end{array}$ & $\begin{array}{l}\text { To test the effectiveness of a } \\
\text { computer-animated tutor, for } \\
\text { teaching new vocabulary items } \\
\text { to children with a hearing loss. }\end{array}$ & $\begin{array}{l}\text { To verify the applicability of a } \\
\text { software in the (re)habilitation of } \\
\text { hearing-impaired children. }\end{array}$ & $\begin{array}{l}\text { To explore the effects of two } \\
\text { different computer-based } \\
\text { exercises for learning the } \\
\text { associations between printed } \\
\text { words and meanings. }\end{array}$ & $\begin{array}{l}\text { To investigate whether the } \\
\text { Corrective Reading-Decoding A } \\
\text { curriculum could be modified to } \\
\text { meet the needs of deaf and hard- } \\
\text { of-hearing learners and result in } \\
\text { enhancing the student's ability to } \\
\text { demonstrate acquisition and } \\
\text { generalization of phonic akills. }\end{array}$ \\
\hline Sample/Age & $N=16, \operatorname{age} 6-11$ & $\mathrm{~N}=8,9-10$ years & $\mathrm{N}=17$, age 6-12 & $\mathrm{N}=11$, average age 7.10 years & $\mathrm{N}=23$, aged $11-15$ years \\
\hline \begin{tabular}{|l|} 
Type and \\
purpose of \\
ICT use
\end{tabular} & $\begin{array}{l}\text { 3D animated interactive software. } \\
\text { To increase the maths skills and } \\
\text { science concepts in deaf children. }\end{array}$ & $\begin{array}{l}\text { Computer, special software. To } \\
\text { provide opportunities for } \\
\text { better communication by } \\
\text { increasing vocabulary. }\end{array}$ & $\begin{array}{l}\text { Computer, special game } \\
\text { software SARDA. The SARDA can } \\
\text { be used by teachers to eliminate } \\
\text { learning and language } \\
\text { difficulties, in order to improve } \\
\text { the children's quality of life. }\end{array}$ & $\begin{array}{l}\text { Laptop and multimedia program. } \\
\text { To read, spell and for } \\
\text { communication with hearing } \\
\text { people. }\end{array}$ & $\begin{array}{l}\text { Computer, special software. To } \\
\text { read and for communication with } \\
\text { hearing people. }\end{array}$ \\
\hline \begin{tabular}{|l|} 
How ICT \\
was \\
measured
\end{tabular} & $\begin{array}{l}\text { Product development. The } \\
\text { evaluation of SMILE includes three } \\
\text { forms: expert panel-based, } \\
\text { formative and summative to } \\
\text { measure the interface appeal. }\end{array}$ & $\begin{array}{l}\text { Intervention: learn new } \\
\text { vocabulary items in special } \\
\text { sofware, } 2 \text { days a week for } \\
\text { about } 10 \text { weeks. Follow-up } \\
\text { after } 4 \text { weeks. Assessment } \\
\text { tests on a set of words } \\
\text { continued before and after } \\
\text { training was completed. }\end{array}$ & $\begin{array}{l}\text { Intervention with a multimedia } \\
\text { program with exercises. The } \\
\text { speech perception ability in quiet } \\
\text { and in noise was assessed } \\
\text { through the Hearing in Noise } \\
\text { Test, before and after the } \\
\text { auditory training. }\end{array}$ & $\begin{array}{l}\text { Intervention with a multimedia } \\
\text { program with exercises. Pre- and } \\
\text { post-test was used to assess } \\
\text { reading and signing skills. }\end{array}$ & $\begin{array}{l}\text { Intervention with a phonic } \\
\text { treatment package. Pre- and post- } \\
\text { test and generalization test was } \\
\text { used to assess reading skills. }\end{array}$ \\
\hline $\begin{array}{l}\text { Reported } \\
\text { benefit of } \\
\text { ICT use }\end{array}$ & $\begin{array}{l}\text { For interface comparisons, there } \\
\text { were no subject effects, but an } \\
\text { animated interface resulted in } \\
\text { reduced time task completion } \\
\text { compared to static interfaces with } \\
\text { and without sound and highlighting. } \\
\text { These findings identify numerous } \\
\text { features that affect software design. }\end{array}$ & $\begin{array}{l}\text { The computer-animated tutor } \\
\text { has been successful in teaching } \\
\text { new vocabulary items to } \\
\text { children with hearing loss. }\end{array}$ & $\begin{array}{l}\text { The auditory training using the } \\
\text { SARDA was effective, providing } \\
\text { improvement of the speech } \\
\text { perception ability, both in quiet } \\
\text { and in noise, for both cochlear } \\
\text { implant, st and hearing aid HAA } \\
\text { userz. }\end{array}$ & $\begin{array}{l}\text { After the training period, on } \\
\text { average, half of the words were } \\
\text { read correctly, whereas one } \\
\text { fourth of the words were spelled } \\
\text { correctly. It is very well possible } \\
\text { for deaf children to learn new } \\
\text { printed words by using } \\
\text { computer-based exercises. }\end{array}$ & $\begin{array}{l}\text { The treatment group had a higher } \\
\text { mean score on phonic post-test } \\
\text { compared to students in the } \\
\text { comparison group. The treatment } \\
\text { group also had a higher mean } \\
\text { score on the general lization test } \\
\text { compared to students in the } \\
\text { comparison group. }\end{array}$ \\
\hline
\end{tabular}

Altogether the analyses indicate that the type of ICT used differed among impairment groups. The results in Table II and III show that text-generating hard- and software was the ICT which was most frequently studied in relation to students with mild motor impairment. Textgenerating hardware was also studied, with a focus on access solutions or as a communication aid in the group of students with severe motor impairment with and without speech impairment. Computer-based communication aids where a type of speech-generating hardware and special software were, for obvious reasons, used for students with difficulties in speaking and communicating (Table IV). Table V shows that ICT, as speech-generating hardware together with special software applications, also occurred in four out of five studies in students with visual impairment. The auditive feedback may be a facilitator in reading and writing, as an option instead of reading and writing with the use of Braille (65). Finally, computers with special multimedia software applications were the types of ICT that had been used and studied in all articles in students with hearing impairment. Regarding how ICT was being used in the 16 intervention studies, Tables II-VI indicated that the purposes of the ICT interventions were 
Running head: BENIFITS OF USING ICT IN SCHOOL

either to compensate for the disability $(42-51,53)$ or to exercise to improve functional capacity $(40,41,52,54,55)$.

\section{Benefits of ICT use in school activities}

The outcomes in studies of students with mild motor impairment with handwriting difficulties (Table II) indicated that computer use with this type of ICT facilitated students' quality in writing (42-44, 46-48), such as decreased spelling errors and increased legibility. However, the students' writing speed had not increased in two $(43,44)$ out of six studies. In a survey, teachers held the opinions that laptop computers increased quality, speed and ease of written output, which improved self-confidence in students with mild motor impairment and also enabled equity with peers (66). Findings in three studies $(42,43,66)$ indicated that conditions in the environment were crucial in terms of whether the outcome of ICT use was successful or not. Examples of beneficial conditions were access to computers and software (portable computers was preferable) and teachers' knowledge of the use of word-prediction programs. Other benefits reported, based on teacher and therapists observation, were children's increased motivation for writing and the fact that writing became less tiring when a computer was used $(44,47,48)$.

In one study (50), the outcomes for students with severe motor impairment (Table III) and their use of access solutions were that ATDs as an intervention strategy were more successful than nine other possible intervention strategies to reach the students' IEP goals in special education. In the intervention studies $(45,49,50)$, one indicated that the writing speed increased in one of two boys (49), another that one student's writing performance had increased through the use of a micro switch (45). Moreover, findings in a survey of students with motor impairment (62) showed that the computer improved opportunities as an educational tool (e.g. 
to search for information), an alternative tool for learning (e.g. to exercise with special software) or as a compensatory tool in school activities (e.g. writing and communicating).

Findings showed positive outcomes relating to educational inclusion in students with speech impairment $(51-53,68,69)$ (Table IV). The students' communications skills $(51-53)$, such as answering and asking questions in class, increased, which facilitated participation in social activities in school and outside school. In one study (68), the students described that they used ICT as communication aids but also as a text-generating device for writing and reading. The AAC system provided also opportunities for independent play (53). Negative descriptions of using communication aid in classes were found, emerging from the students who used the devices, e.g. insufficient vocabularies, lack of related services, as well as poor usability (52, 69).

The outcome in studies related to visual impairment indicated (Table V) that all new products holds promise $(56,58,59)$, e.g. provided a functional text-entry solution for students with low vision (59), even if the students had comments on the design of the products. The two $(56,58)$ intervention studies with the purpose of increasing the maths skills of youths with visual impairments showed that the students' performance in maths was significantly better when using the special software. In addition, parents and teachers reported that use of ICT promoted social inclusion and facilitated schoolwork by students with visual impairment (65, 70). Despite this, the result from one of the descriptive studies with 58 participating teachers who teach students with visual impairment (65) showed that most of them (95\%) did not use ICT in the target group.

Students' knowledge in vocabulary and phonic skills was measured in three studies before and after the intervention. The outcomes $(40,54,55)$ showed that students with hearing impairments (Table VI) benefited from visual feedback from the computer and multimedia software, e.g. signs created as an avatar, or a combination of images of the words clarified by 
lip reading, to facilitate reading. In the fourth intervention study (40), the test found that auditory training using special software was effective, providing improvement in the speechperception ability for the 17 participating children. However, in the study (41) where two 3D animated interactive software applications for teaching maths and science to deaf students were tested, showed no subject effects.

\section{Discussion}

The aim of this review is to investigate type of ICT items and how ICT is being used by students with physical disabilities, and describe benefits of ICT use in school activities. The present study was designed to investigate the use of ICT in school activities among students with different types of physical disabilities, such as motor, visual, hearing and communication impairment. This turned out to be necessary in order to obtain a sufficient number of articles for analysis. In addition, this makes it possible to compare the use of ICT between students with a variety of difficulties in participating in school activities. When comparing ICT use, findings in present review show that the type of ICT provides different opportunities depending on the students' impairment group. It can be interpreted that ICT can be seen as a flexible device by compensating for diverse impairments, such as motor, speech, visual and hearing difficulties.

Furthermore, two different purposes appeared when the aims of the interventions of ICT use in the studies were analysed: to compensate for the students' difficulties and to practise with the help of the ICT to increase functional capacity. In both cases ICT has been used as ATD, which has been studied for many years in children with motor impairments $(72,73)$. However, the results in present study provide some evidence that use of computer and special software improves students' writing ability, in terms of speed, legibility and spelling. Despite the fact that the evidence level is low with small numbers of participants, this is a positive 
outcome, as writing is an important activity in school, and a prerequisite for participation in other educational activities. In a study of children without disabilities findings showed that writing by keyboard does not necessarily lead to improvements in the amount of written text (75). This result makes us understand that, for some students with physical disabilities, computer use has specific opportunities to facilitate writing, but computing does not improve writing for all students. The computer as a writing tool has been used for many years, so one unanticipated finding was that only studies in students with motor or speech impairment have been found, but no studies e.g. in students with visual impairment. This is true in spite of findings that indicate that computer and speech synthesis are beneficial tools for students with visual impairment in maths, and should also be beneficial in writing. Are the benefits so obvious and therefore uninteresting to study, or is the tradition in ATD research to focus on product development such as special software and access solutions, rather than to investigate the benefits of the ATDs on students' school performance, such as writing?

In the studies included findings indicate that ICT can be considered to improve writing in speed and script quality for some students. Nevertheless research is still sparse on the benefits of ICT use where writing is an activity in occupations and in today's and future education. MacArthur (76) point out that it is clear that digital skills such as searching for information online, integrating multimedia in writing, and writing online will be important digital skills today and in the future. This research needs to go further and evaluate the new ICT critically but proactively, so systemic improvements can be made in the students' environment and in the development of ICT.

Every effort was made to undertake a thorough review of the literature pertaining to the benefit of ICT use in school activities in students with physical disabilities. However, there are limitations to this review, for example in the selection of keywords. If an assistive technology in a paper was not identified as an ICT or computer-based assistive technology the 
paper may not have been incorporated in the search process. Another limitation is that only one of the authors was responsible for the literature search. This may have an impact on the findings, but the results were discussed on several occasions, and the interpretation was done by both authors in collaboration. An explanation regarding sparse research in this area involves findings in an overview of systematic reviews of the effectiveness of ATD use in general by people with disabilities. Their review stated that research on the effectiveness of ATD, and especially evidence concerning ATDs for children and young people, was missing (31) from the literature. The results in present review show that only half of the studies are intervention studies and the other half are of the descriptive type or constitute tests of new products for students with physical disabilities.

The lack of intervention studies is not unexpected since earlier research identified difficulties in including ICT in education $(11,27,77,78)$ and students' dissatisfaction with access to the computer-based ATDs affects the use of ICT in schools (30). Findings in the descriptive studies showed that ICT is not used in schools to the extent that was desirable from the students' perspective $(62,71)$.

Benefits of ICT use in the interventions studies were often measured from a functional perspective, e.g. decreased spelling errors, improvement in the speech-perception ability, and performance in maths. The functional perspective often assumes that children always choose to use an ATD to compensate for their impairment. However, psychosocial aspects, such as how the ATD influenced children' self-images and peer reactions to the ATD, appeared to be important from the children' perspective $(26,71)$. Thus findings indicated that psychosocial aspects in relation to performance opportunities are important when children chose whether ATDs were worth using or not. It is documented that outcomes of ATD are depicted as resulting from the interaction among different characteristics: specific 
device-type, its users, and their environment $(79,80)$. A good match of these aspects is essential if the technology may be used, or will be used optimally (79).

Accordingly, difficulties in measuring the outcomes of the ICT use are complex and therefore might be another explanation for why few intervention studies were found. No RCT studies were identified, and only two studies had a control group. Scholars in the area point out the need to develop new methods for assessing research quality in this area $(31,81)$, especially for situations when control groups or large samples are not possible, i.e. in situations that often occur within ATD outcomes research (82).

Finally, the answer to the question in the introduction is still that ICT has the potential to be used for many different types of activities $(9,62,74)$. Only a small amount of evidence to support the use of ICT was found to promote the inclusion of students with physical disabilities to achieve equal opportunities in education, thus facilitating school tasks and social interactions. The review found that empirical studies in nature contexts is still missing in benefits of ICT use by students with physical disabilities, mainly in relation to students with visual, hearing and communication impairment.

\section{Conclusion}

Despite considerable heterogeneity across the studies, the literature reviewed appears broadly to support that students with physical disabilities benefit from ICT use in schools, regardless of the type of ICT. ICT seems especially beneficial for writing, spelling and communication. For future research it is important to highlight intervention studies to investigate whether ICTs are powerful educational tool for students with physical disabilities, such as motor, visual, hearing and communication impairment - not just as an ATD to compensate for or remediate the impairment for students with physical disabilities. This complexity is also a reason why there is limited evidence of ICT use in schools by students with physical disabilities (31). 


\section{References}

1. Hakkarainen K, Ilomäki L, Lipponen L, Muukkonen H, Rahikainen M, Tuominen T, et al. Students' skills and practices of using ICT: results of a national assessment in Finland. Comput Edu. 2000;34:103-17.

2. Lei J, Zhao Y. Technology uses and student achievement: A longitudinal study. Comput Edu. 2007;49:284-96.

3. Li N, Kirkup G. Gender and cultural differences in Internet use: A study of China and the UK.Comput Edu. 2007;48:301-17.

4. Hayes D. ICT and learning: Lessons from Australian classrooms.Comput Edu. 2007;49:385-95.

5. Gülbahar Y. Technology planning: A roadmap to successful technology integration in schools.Comput Edu. 2007;49:943-56.

6. Ilomäki L, Rantanen P. Intensive use of ICT in school: Developing differences in students' ICT expertise.Comput Edu. 2007;48(1):119-36.

7. Ciccarelli M, Straker L, Mathiassen S, Pollock C. ITKids Part I: Children's occupations and use of information and communication technologies. Work. 2011;38:401-12.

8. United Nations. Convention on the Rights of Persons with Disabilities and Optional Protocol. New York: United Nations enable; 2008 [100414]; Available from: http://www.un.org/disabilities/default.asp?id=150.

9. Shane H, Blackstone S, Vanderheiden G, Williams M, DeRuyter F. Using AAC Technology to Access the World.Assist. Technol. 2012;24:3-13.

10. Gillette Y. Assistive technology and literacy partnerships. Top Lang Disord. 2006;26:70-84.

11. Chantry J, Dunford C. How do computer assistive technologies enhance participation in childhood occupations for children with multiple and complex disabilities? A review of the current literature. Br J Edu Technol. 2010;73:351-65.

12. Rose D, Hasselbring T, Stahl S, Zabala J. Assistive Technology and Universal Design for Learning: Two Sides of the Same Coin. In: Edyburn D, Higgins K, Boone R, editors. Handbook of Special Education Technology Research and Practice: Knowledge By Design, Inc.; 2005. p. 507-18.

13. Samuelsson U. ICT use among 13 - year - old Swedish children. Learn Media Technol. 2010;35:1530.

14. Hasselbring T, Glaser C. Use of computer technology to help students with special needs. Future child. 2000;10:102-22.

15. Brodin J, Renblad K. How many positive results on inclusion do we need to make changes? In: Emiliano Pea, editor. Assistive Technology from Adapted Equipment to Inclusive Environments AAATE 2009. Netherlands: IOS Press; 2009. p. 708-12.

16. Brodin J, Lindstrand P. Are computers the solution to support development in children in need of special support? Technol Disabil. 2004;16:137-45.

17. Emiliano PL, Stephanidis C, Vanderheiden G. Technology and inclusion - Past, present and foreseeable future. Technol Disabil. 2011;23:101-14.

18. Desch L, Gaebler-Spira D. Prescribing Assistive-technology Systems: Focus on Children With Impaired Communication. J Pediatr. 2008;12:1271-80.

19. World Health Organization. International Classification of Functioning, Disability and Health (ICF). Geneva: World Health Organization; 2001.

20. Campbell P, Milbourne S, Dugan L. A Review of Evidence on Practices for Teaching Young Children to Use Assistive Technology Devices. Topics Early Child Spec Educ. 2006;26:3-11.

21. Isabelle S, Bessey F, Lawrence Dragas K, Blease P, Shephard J, Lane S. Assistive technology for children with disabilities. Occup Ther Health Care. 2002;16:29-51.

22. Almqvist L, Granlund M. Participation in school environment of children and youth with disabilities: a person- oriented approach. Scand J Psychol. 2005;46:305-14.

23. Odabaşi F, Kuzu A, Girgin C, Çuhadar C, Kıyıcı M, Tanyeri T. Reflections of hearing impaired students on daily and instructional PDA use. Int J Spec Educ. 2009;24:8-19.

24. Söderström S. Offline social ties and online use of computers: A study of disabled youth and their use of ICT advances. New Media \& Soc. 2009;11:709-27. 
25. Law M, Petrenchik T, King G, Hurley P. Perceived environmental barriers to recreational, community, and school participation for children and youth with physical disabilities. Arch Phys Med Rehabil. 2007;88:1636-42.

26. Skär L. Disabled children's perceptions of technical aids, assistance and peers in play situations. Scand J Caring Sci. 2002;16:27-33.

27. Wisdom J, White N, Goldsmith K, Bielavitz S, Rees A, Davis C. Systems Limitations Hamper Integration of Accessible Information Technology in Northwest U.S. K-12 Schools. Edu Technol \& Soc. 2007;10:222-32.

28. Copley J, Ziviani J. Barriers to the use of assistive technology for children with multiple disabilities. Occup Ther Int. 2004;11:229-43.

29. Craddock G. The AT continuum in education: Novice to power user. Disabil Rehabil Assist Technol. 2006;1:17-27.

30. Lidström H, Almqvist L, Hemmingsson H. Computer-based assistive technology device for use by children with physical disabilities: a cross-sectional study. Disabil Rehabil Assist Technol. 2012;7:287-93.

31. Anttila H, Samuelsson K, Salminen A-L, Brandt Å. Quality of evidence of assistive technology interventions for people with disability: An overview of systematic reviews. Technol Disabil. 2012;24:9-48.

32. Aveyard H. Doing a literarure review in health and social care. A practical guide. 2 ed. Berkshire, UK Open University Press; 2010.

33. Polit DF, Beck CT. Nusing research: generating and assessing evidence for nursing practice 8 , editor. Philadelphia: Lippincott Williams \& Wilkins; 2008.

34. Forsberg C, Wengström Y. Att göra systematiska litteraturstudier [To do systematic literature reviews]. Stockholm, Sweden: Natur och Kultur; 2003.

35. Schlosser R, Koul R, Costello J. Asking well-built questions for evidence-based practice in augmentative and alternative communication. J Commun Disord. 2007;40:225-38.

36. Tomlin G, Borgetto B. Research Pyramid: A New Evidence-Based Practice Model for Occupational Therapy. Am J Occupl Ther. 2011;2:189-96.

37. Law M, Stewart D, Letts L, Pollock N, Bosch J, Westmorland M. Guidelines for critical review form-Quantitative studies. Hamilton: McMaster University, Canada1998.

38. Letts L, Wilkins S, Law M, Stewart D, Bosch J, Westmorland M. Guidelines for critical review form: Qualitative studies (Version 2.0). Hamilton: McMaster University, Canada2007.

39. Law M, Stewart D, Letts L, Pollock N, Bosch J, Westmorland M. Guidelines for critical review form-Qualitative studies. Hamilton: McMaster University, Canada1998.

40. Trezek B. The Efficacy of Utilizing a Phonics Treatment Package with Middle School Deaf and Hard-of-Hearing Students. J. Deaf Stud. Deaf Educ. 2005;10:257-71.

41. Perin da Siliva M, Comerlatto Junior A, Andreoli Balen S, Bevilacqua M. Software use in the (re)habilitation of hearing impaired children. J Soc Bras Fonoaudiol. 2012;24:34-41.

42. Handley-More D, Delitz J, Billingsley F, Coggins T. Facilitating written work using computer word processing and word prediction. Am J Occup Ther. 2003;57:139-59

43. Hetzroni O, Shrieber B. Word processing as an assistive technology tool for enhancing academic outcomes of students with writing disabilities in the general classroom. J Learn Disabil. 2004;37:143-54.

44. Klein S, Erickson L, James K, Perrott K, Williamson H, Zacharuk L. Effectiveness of a Computer Skills Program to Improve Written Communication in Children with Developmental Coordination Disorder. Phys Occup Ther Pediatr. 2008;28:5-23.

45. Lancioni G, Singh N, O'Reilly M, Sigafoos J, Green V, Oliva D, et al. Microswitch and keyboardemulator technology to facilitate the writing performance of persons with extensive motor disabilities. Res Dev Disabil. 2011;32:576-82.

46. Mirenda P, Turoldo K. The Impact of Word Prediction Software on the Written Output of Students with Physical Disabilities. J Spec Educ Technol. 2006;21:5-12.

47. Tam C, Archer J, Mays J, Skidmore G. Measuring the outcomes of word cueing technology. Can J Occup Ther. 2005;72:301-8. 
48. Tumlin J, Wolff Heller K. Using Word Prediction Software to Increase Typing Fluency with Students with Physical Disabilities. J Spec Educ Technol. 2004;19:5-14.

49. Lancioni G, Singh N, O'Reilly M, Sigafoos J, Green V, Chiapparino C, et al. A voice-detecting sensor and a scanning keyboard emulator to support word writing by two boys with extensive motor disabilities. Res Devl Disabil. 2009;30:203-9.

50. Watson A, Ito M, Smith R, Andersen L. Effect of assistive technology in a public school setting. Am J Occup Ther. 2010;64:18-29.

51. Myers C. "Please listen, it's my turn'”: Instructional approaches, curricula and contexts for supporting communication and increasing access to inclusion. J. Intellect. Dev Disabil. 2007;32:263-78.

52. Raghavendra P, Oaten R. Effects of speech and print feedback on spelling performance of a child with cerebral palsy using a speech generating device. Disabil Rehabil Assist Technol. 2007;2:299308.

53. Salminen A, Ryan S, Petrie H. Impact of computer augmented communication on the daily lives of speech-impaired children. Technol Disabil. 2004;16:169-77.

54. Massaro D, Light J. Improving the Vocabulary of Children with Hearing Loss. Volta Rev. 2004;104:141-74.

55. Reitsma P. Computer-Based Exercises for Learning to Read and Spell by Deaf Children. J. Deaf Stud. Deaf Educ. 2009; 14:178-89.

56. Beal C, Rosenblum P, Smith D. Pilot Study of a Self-Voicing Computer Program for Prealgebra Math Problems. J Visual Impairment Blind. 2011;105:157-69.

57. Leung B, Chau T. A multiple camera tongue switch for a child with severe spastic quadriplegic cerebral palsy. Disabil Rehabil Assist Technol. 2010;5:58-68.

58. Landau S, Russell M, Gourgey K, Erin JN, Cowan J. Use of the Talking Tactile Tablet in Mathematics Testing. J Visual Impairment Blind. 2003;97:85-97.

59. Leung B, Yates M, Duez P, Chau T. Text Entry via Character Stroke Disambiguation for an Adolescent With Severe Motor Impairment and Cortical Visual Impairment. Assist Technol. 2010;22:223-35.

60. Adamo-Villani N, Wibur R. Software for math and science education for the deaf. Disability and Rehabilitaion: Assist Technol. 2010;5:115-24.

61. Brodin J. "Can ICT Give Children with Disabilities Equal Opportunities in School?". Improving Schools J. 2010;13:99-112.

62. Lidström H, Granlund M, Hemmingsson H. Use of ICT in school: A comparison between students with and without physical disabilities. Eur J Spec Needs Educ. 2012;27:21-34.

63. Murchland S, Parkyn H. Promoting Participation in Schoolwork: Assistive Technology Use by Children With Physical Disabilities. Assist Technol. 2011;23:93-105.

64. Pousada García T, Pereira Loureiro J, Groba González B, Nieto Riveiro L, Pazos Sierra A. The Use of Computers and Augmentative and Alternative Communication Devices by Children and Young With Cerebral Palsy. Assist Technol. 2011;23:125-39.

65. de Freitas Alves C, Martins Monteiro G, Rabello S, Rodrigues Freire Gasparetto M, Monteiro de Carvalho K. Assistive technology applied to education of students with visual impairment. Rev Pan Am Salud Publica. 2009;26:146-52.

66. Priest N, May E. Laptop computers and children with disabilities. Aust Occup Ther J. 2001;48:11-.

67. Murchland S, Parkyn H. Using assistive technology for schoolwork: the experience of children with physical disabilities. Disabil Rehabil Assist Technol. 2010;5:438-47.

68. Carpe A, Harder K, Tam C, Reid D. Perceptions of writing and communication aid use among children with a physical disability. Assist Technol. 2010;22:87-98.

69. Kent-Walsh J, Light J. General Education Teachers' Experiences with Inclusion of Students who use Augmentative and Alternative Communication. Augment Alternat Communicat. 2003;19:10424.

70. Kelly S. Use of assistive technology by students with visual impairments: findings from a national survey. J Visual Impairment Blin. 2009;103:470-80.

71. Hemmingsson H, Lidström H, Nygård L. The use of Assistive Technology Devices in mainstream schools: the students' perspective. Am J Occup Ther. 2009;63:463-72. 
72. Derer K, Polsgrove L, Rieth H. A Survey of Assistive Technology Applications In Schools and Recommendations for Practice. J Spec Educ Technol. 1996;XIII:62-80.

73. Unsworth C, Townsend M. Occupational therapists'skills and attitudes regarding use of computers and assisistive technology. Occup Ther Int. 1997;4:52-65.

74. Fredriksson U, Gajek E, Jedeskog G. Ways to use ICT in schools to optimize the impact on teaching and learning. Acta Didact. Napocensia. 2009;2:21-32.

75. Connelly V, Gee D, Walsh E. A comparison of keyboarded and handwritten compositions and the relationship with transcription speed. Br J Educ Psychol. 2007;77:479-92.

76. MacArthur C. Reflections on Research on Writing and Technology for Struggling Writers. Learn Disabil Res Pract. 2009;24:93-103.

77. Brodin J, Lindstrand P. What about ICT in special education? Special educators evaluate Information and Communication Technology as a learning tool. Eur J Spec Needs Educ. 2003;18:71-87.

78. McDonald R, Harris E, Price K, Jolleff N. Elation or frustration? Outcomes following the provision of equipment during the Communication Aids Project: data from one CAP partner centre. Child Care Health Dev. 2007;34:223-229.

79. Scherer, M., \& Craddock, G. Matching Person \& Technology (MPT) assessment process. Technol Disabil. 2002;14:125-131.

80. Fuhrer, M. J., Jutai, J. W., Scherer, M. J., \& Deruyter, F. A framework for the conceptual modelling of assistive technology device outcomes. Disabil Rehabil. 2003;25:1243-1251.

81. Smith, R. Measuring Assistive Technology Outcomes in Education. Diag. 2000;25:273-90.Vincent C, Routhiera F. Designs in AT research: Usefulness for therapists in clinical practice. Technol Disabil. 2012;24:49-58. 